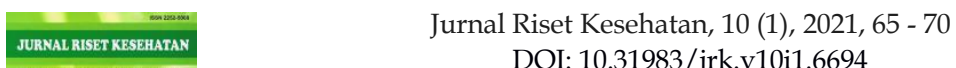

DOI: $10.31983 /$ jrk.v10i1.6694

Jurnal Riset Kesehatan

http://ejournal.poltekkes-smg.ac.id/ojs/index.php/jrk

\title{
HOUSE ENVIRONMENTS AS RISK FACTORS OF TUBERCULOSIS IN CILACAP DISTRICT
}

\author{
Imam Agus Faizal ${ }^{a^{*}}$; Ira Pangesti ${ }^{\mathrm{b}}$; Denih Agus Setia $\mathrm{P}^{\mathrm{c}}$ \\ a,b Medical Labolatory Technology of Bachelor Applied Department ; 24 Cerme street \\ Kabupaten Cilacap 53223 ; Indonesia \\ c D3 Pharmacy of Department ; 24 Cerme street ; Kabupaten Cilacap 53223 ; Indonesia
}

\begin{abstract}
Tuberculosis (TB) is a disease caused by the bacterium Mycobacterium tuberculosis which is still a major global health problem in the world and causes morbidity rates in millions of people each year. new cases of positive BTA in Central Java in 2017 amounted to 60.91 per 100,000 population. Meanwhile, based on the profile of the Cilacap District Health Office in 2018, the number of TB sufferers reached 5271 cases, around 1089 TB cases that have not been found and reported, while 34 of them died. The purpose of this study was to analyze the risk factors for tuberculosis incidence in Cilacap Regency. The purpose of this study was to analyze House Environments As Risk Factors Of Tuberculosis In Cilacap District. This type of research is an observational analytic quantitative approach with a research design that is using case control and cross-sectional which was conducted from May 2020 to June 2020 in the work area of the RSUD Cilacap Paru Center. The Respondents this research is the person who lived in the work area of the public health center using total sampling technique so that it is obtained 30 respondents. This study concludes significant effect on floor types, natural ventilation and housing density. Meanwhile, the respondent's characteristic factors such as smoking habit, phlegm discharge habit and coughing and sneezing influenced the incidence of tuberculosis.
\end{abstract}

Keywords: risk factor; tuberculosis; Mybacterium tuberculosis

\section{Introduction}

Mycobacterium tuberculosis (Mtb) is the cause of tuberculosis (TB) in humans which causes death and is one of the infectious agents in humans in the world. The bacterium Mycobacterium tuberculosis, which causes tuberculosis, is a chronic infectious disease in the form of a rod known as acid-resistant bacteria (Sinaga, 2019). Bacteriological examination aims to identify the bacteria Mycobacterium tuberculosis using patient sputum specimen material (Budiharjo \& Purjanto, 2016). There are an estimated 8.7 million new cases, 1.4 million deaths, and about 2 billion latent infections caused by Mtb (Fitzgerald et al. 2014). According to WHO (World Health Organization) in 2014, an estimated 9.6 million people transmitted active TB disease, of which 1.5 million died. Based on

*) Corresponding Author (Imam Agus Faizal)

E-mail: imamdfaizal@stikesalirsyadclp.ac.id data from the Indonesian Ministry of Health in 2017, TB cases in Indonesia reached 1,000,000 cases and the number of deaths due to TB is estimated at 110,000 cases each year (Faizal et al., 2018). In Central Java there were as many as 42,272 cases of tuberculosis in 2017 of the total population 18,248 of $34,257,865$ were examined for acid-resistant bacilli (10,614 men and 7,734 women). The total case notification rate (CNR) is 123 and the number of smear positive was 53 . Total positive pulmonary tuberculosis recovered 11,758 or $93.07 \%-876$ or $6.93 \%$ with complete treatment. Treatment success was 12,634 or 72.84\% (Djoko \& Widodo, 2020).

In addition, health status is influenced by several factors, namely environment, behavior, health services and heredity. The biggest factors affecting the degree of health are environmental factors and people's own behavior that can harm health. Tuberculosis is an environmentally based disease. The risk factors for tuberculosis 
transmission are environmental factors and behavioral factors, environmental factors include ventilation, housing density, temperature, lighting and humidity. Meanwhile, behavioral factors include smoking, spitting or expelling phlegm in any place, coughing or sneezing not covering your mouth and not opening windows (Wulandari et al., 2015). The purpose of this study was to analyze the risk factors for tuberculosis that were correlated with the physical characteristics of the house including floor types, housing density, natural ventilation with pulmonary TB incidence in the working area of the RSUD Cilacap Paru Center Hospital. While the hypothesis this research is to find out there or there is no relationship between the physical characteristics of the house with the incident in the RSUD Cilacap Paru Center working area.

\section{Method}

This type of research is an observational analytic quantitative approach with a research design that is using case control and cross-sectional which was conducted from May 2020 to June 2020 in the work area of the RSUD Cilacap Paru Center. The Respondents this research is the person who lived in the work area of the public health center using total sampling technique so that it is obtained 30 respondents. The respondent were taken provided that they met the inclusion criteria that had been determined were obtained as many The subjects of the study consisted of 15 non-patient respondents and 15 respondents with positive pulmonary tuberculosis (BTA) examination.

The inclusion criteria to determine respondent size were patients with pulmonary tuberculosis who tested positive for Acid-Resistant Basil (BTA), residents domiciled in Cilacap, willing to participate in the study, had not been treated for TB for 6 months. Meanwhile, the exclusion criteria were that the respondent was not present at the time of data collection and the patient was not domiciled in Cilacap. Data collection in the study was carried out using the observation check list. The research measuring tool used is the roll meter to measure the area of the meter to determine the housing density of the house, the floor type is measured based on KepMenkes RI No.829 / Menkes / SK / VII / 1999 recommends that the type of floor meets health requirements while natural ventilation meets the health criteria based on
Permenkes RI No.1077 / Menkes / Per / V / 2011.

The independent variables studied in this study were housing density, natural ventilation, and floor type. While the dependent variable in the study was the incidence of pulmonary tuberculosis. While the moderator variable is participants (not respondents) who have characteristics including the habit of opening windows, the habit of throwing out phlegm, the habit of coughing and sneezing, the habit of smoking.

Data analysis included univariate and bivariate analyzes. Univariate analysis, namely descriptively using frequency distribution tables. Bivariate analysis is analytic to determine the relationship between two variables with the chi square test to see the amount of risk with odds ratio (OR).

\section{Result and Discussion}

Table 1 . The results of bivariate analysis based on the independent variables in the study

\begin{tabular}{lcccc}
\hline \multirow{2}{*}{ Variables } & \multicolumn{2}{c}{$\begin{array}{c}\text { Incidences of } \\
\text { tuberculosis }\end{array}$} & p-value & 95\% CI \\
\cline { 2 - 3 } & $\mathrm{n}$ & $\%$ & & \\
\hline Floor types & & & & $1.4333-0.50401$ \\
\hline $\begin{array}{l}\text { Not water } \\
\text { proof }\end{array}$ & 17 & 56.7 & & \\
$\begin{array}{l}\text { Water proof } \\
\text { Natural }\end{array}$ & 13 & 43.3 & & \\
$\begin{array}{l}\text { ventilation } \\
\text { not eligible }\end{array}$ & 11 & 36.7 & & $1.6333-0.49013$ \\
qualify & 19 & 63.3 & 0.001 & \\
\hline $\begin{array}{l}\text { Housing } \\
\text { density }\end{array}$ & & & & \\
\hline $\begin{array}{l}\text { not eligible } \\
\text { qualify }\end{array}$ & 11 & 36.7 & & \\
\hline
\end{tabular}

The results of the above analysis showed that a total of 30 samples had a significant correlation between the type of floor and the incidence of tuberculosis, which was obtained $(p$-value $=0.001)$. This greatly affects the health factors of the home environment related to the physical condition of the house and individual characteristics (Rosiana, 2012). The risk is greater than having a house that is not waterproof, about 2.85 times than that of a house that has a waterproof floor type (Kartono, 2008). Houses in Cilacap Regency are mostly made from waterproof materials, and some are not ceramic or porcelain, tile or cement. KepMenkes RI No.829 / Menkes / SK / VII / 1999 recommends 
that types of floors that meet health requirements are waterproof and easy to clean, such as types of floors made of plaster, tiles, cement, porcelain or ceramic, while types of floors that are not fulfilling health requirements is not waterproof such as the type of ground floor, boards, and palm trees (Andreas, 2012).

This type of plank or stilt floor can cause an increase in humidity in the house because the planks are not a waterproof material and influence soil moisture. To prevent moisture from occurring in a house with a plank floor type, it is necessary to cover it with a rubber mat that functions as a waterproof base so that it can protect against water and moisture seepage (Sukmajati, 2010). A humid room is a place for disease vectors and bacteria to breed, so the construction of the house floor must be tight and always dry against water and cause humidity. This type of waterproof floor can prevent the risk of tuberculosis (Widoyono, 2012).

The results of the above analysis showed that from a total of 30 samples there was no correlation between natural ventilation and the incidence of tuberculosis, which was obtained ( $\mathrm{p}$-value $=0.001) . \mathrm{A}$ total of 15 negative respondents with tuberculosis, 9 had met the requirements, natural ventilation can also be accomplished by leaving the windows open on the opposite side of the room. The requirements for natural ventilation in this study that distinguish it from previous studies are that the ventilation design in the coastal district of Cilacap is different from other areas. The natural ventilation design is mostly in the bottom hung type of cilacap, namely the flow of air generated downward depending on the angle of the opening. While 9 of the 15 respondents did not meet the requirements. Permenkes RI No.1077 / Menkes / Per / V / 2011. Poor ventilation in the respondent's house is caused by the narrow and close proximity of the house to one another so that it does not allow ventilation in the room where the gathering is located.

The area of the respondent's house is also a densely occupied area so that the space between the houses does not have a large enough area. Natural ventilation is measured by comparing the area of the ventilation with the floor area. Fulfilling the requirements for natural ventilation of the respondent's house can be caused by several things such as the area of the house that is not proportional to the area of the ventilation and windows or vents made of glass that cannot be opened. Some of the respondents' houses have vents that can be opened and closed. Closed windows lead to poor house ventilation thereby increasing the risk of contracting tuberculosis (Lyzigos \& Melissa 2013). Respondents in the case above are orderly in opening the window vents so that air circulation and sunlight can enter the room, which has the potential to kill the Mycobacterium tuberculosis bacteria (Achmadi, 2008).

The results of the above analysis showed that a total of 30 samples had a correlation between housing density and the incidence of tuberculosis, which was obtained ( $\mathrm{p}$-value = 0.001). Tuberculosis is easy to spread in relation to the larger the occupancy in one house because the potential for interaction occurs between residents in one house (Heriyani, 2013). Housing density for the entire house usually expressed in $\mathrm{m} 2$ / person. Large the minimum per person is very relative, it depends of the quality of the building and its facilities available. Comparison of the number of residents by area the room of the house occupied by the respondent inside unit square meter $(\mathrm{m} 2)$, with the requirements minimum $8 \mathrm{~m} 2 /$ person (Mariana \& Hairuddin, 2018). Research states that the incidence of tuberculosis is also related to housing density in terms of epidemiological description methods (Ndungu, 2013). Previous studies also described populations custom house occupancy does not meet the requirements have a 2.5 times higher risk for suffers from $\mathrm{Tb}$ in comparison with that house the housing density meets the requirements. Respondents who surround the house do not qualify risk of 2.74 times higher for pulmonary tuberculosis than for the home qualify. (Indra Martias \& Hendra Dhermawan, 2018). Based on what has been stated on the theoretical basis, overcrowded housing density is a prerequisite for the process of disease transmission, especially through air (it will be easier and faster). The size of the house that is not proportional to the number of residents will cause a lack of oxygen consumption, and if one of the family members has a disease such as tuberculosis infection, it will be easy to infect other family members (Suryo, 2010). 
Table 2. The results of multivariate analysis based on the independent variables in the study

\begin{tabular}{lccccc}
\hline \multicolumn{1}{c}{ Variables } & \multirow{2}{*}{$\mathrm{B}$} & \multirow{2}{*}{ P-Value } & \multirow{2}{*}{$\mathrm{T}$} & \multicolumn{2}{c}{95,0 \% CI OR } \\
\cline { 5 - 6 } & & & & Lower & Upper \\
\hline Floor types & 1.433 & 0.000 & 15.577 & 1.245 & 1.622 \\
Natural ventilation & 1.633 & 0.000 & 18.252 & 1.450 & 1.816 \\
Housing density & 1.633 & 0.000 & 18.252 & 1.450 & 1.816 \\
The habit of opening windows & 1.800 & 0.000 & 24.233 & 1.648 & 1.952 \\
The habit of throwing out phlegm & 1.400 & 0.000 & 15.389 & 1.214 & 1.586 \\
The habit of coughing and sneezing & 1.167 & 0.000 & 16.858 & 1.025 & 1.308 \\
The habit of smoking. & 1.300 & 0.000 & 15.277 & 1.126 & 1.474 \\
\hline
\end{tabular}

The results of multivariate analysis of statistical tests carried out on variable smoking habits of families with the incidence of pulmonary tuberculosis indicates the statistically significant relationship between family smoking habits with incidence Tuberculosis $(\mathrm{p}=0.000)$. Description of smoking behavior on the case group shows it all smoking more than 10 cigarettes per day, in fact there are nearly $40 \%$ who smoke more than 20 stems per day. People who smoke will more at risk of getting tuberculosis caused because smoking can interfere with effectiveness part of the respiratory defense mechanism. Smoking in the home is a factor risk for incidence of smear pulmonary TB positively, indoor air pollution from smoke smoking can increase your risk of becoming infected M. tuberculosis (Sejati \& Sofiana, 2015).

The results of the analysis of the habit of throwing sputum showed that there was a relationship with the incidence of TB $(p=0.000)$. The habit of throwing phlegm is a the activity of throwing out phlegm or saliva that comes from mouth carried by someone. Throw away sputum or spit anywhere you can increase the spread of pulmonary $\mathrm{TB}$ germs, causing $\mathrm{TB}$ germs to develop and live so that they have the opportunity to transmits germs if phlegm or saliva is thrown in any place. habit of expelling phlegm random places with the incidence of pulmonary tuberculosis or in the open have a role in the occurrence of pulmonary tuberculosis because it can be possible Mycobacterium tuberculosis will survive live in the air a few hours for 20-30 hours except there is sunlight (ultraviolet). This can potentially infect someone if these droplets inhaled and passed into the respiratory tract. If a patient with pulmonary tuberculosis expels phlegm random places for example sputum thrown in home or outside the room, thrown in the tin that has been given lisol or without lisol, then with these suitable temperature and humidity conditions can survive and reproduce, these bacteria will still exist in the environment and at any time can infect healthy people (Yigibalom et al., 2019).

Meanwhile, the habit of coughing and sneezing, seen from the results of the above test analysis, also showed an influence between cough habit and the incidence of tuberculosis ( $p$ $=0.000)$. This finding is necessary get serious attention, because when coughing or sneezing, TB patients can spread it germs into the air in the form of sparks sputum (droplet nuclei). One cough can generates about 3000 sparks sputum. Research has also found a high risk transmission due to non-compliance with use masks for TB sufferers. On the other hand, research proves that masks are an effective way for TB prevention. On the contrary, in the prevention component in the form of cough ethics (80.3\%) and medication $(73.8 \%)$ is a component of prevention with the highest percentage of good categories (Wati et al., 2020).

\section{Conclusion and Suggestion}

Based on the results of the study, it can be concluded that House Environments As Risk Factors Of Tuberculosis In Cilacap District has a significant effect on floor types, natural ventilation and housing density. Meanwhile, the respondent's characteristic factors such as smoking habit, phlegm discharge habit and coughing and sneezing influenced the incidence of tuberculosis. The suggestion from this research is that the researchers recommend to continue to increase efforts for preventive activities and promotion of risk factors for Lung Tuberculosis which are influenced by environmental factors. While the follow-up, the community should be able to improve the physical condition of the house environment, especially in increasing ventilation in the house in order to facilitate air circulation and and changing the characteristics of a healthy life. 


\section{Acknowledgments}

I would like to thank all those who helped in this research. LPPM STIKES Al Irsyad Al Islamiyyah Cilacap, Bappeda Cilacap, Cilacap Regional Hospital and Cilacap District Health Office and all those involved in this research.

\section{References}

Budiharjo, T., \& Purjanto, K. A. (2016). Pengaruh Penanganan Sputum Terhadap Kualitas Sputum Penderita Tbc Secara Mikroskpis Bakteri Tahan Asam. Jurnal Riset Kesehatan, 5(1), 40-44.

Djoko, P., \& Widodo. (2020). Detection Of The Resistance Of Mycobacterium Tuberculosis From Specimens With $\mathrm{Tb}$ Patients In Semarang Balkesmas. Jurnal Riset Kesehatan, $9(1), \quad 16 \quad-\quad 19$. https://doi.org/10.31983/jrk.v9i1.5583

Faizal, I. A., Dwi, A., Widodo, W., \& Nugraha, J. (2018). The Effect of Macrophage Dose to Secretion Interleukin 6 ( IL-6) on Model of Tuberculosis Granuloma In Vitro. Proceedings of the 2 nd International Conference Postgraduate School (ICPS), 6, $306-311$. https://doi.org/10.5220/0007541803060311

Indra Martias, \& Hendra Dhermawan, S. (2018). Karakteristik Fisik Rumah Dengan Kejadian $\mathrm{Tb}$ Paru Di Wilayah Kerja Puskesmas Sei Jang Kota Tanjungpinang. Jurnal Riset Kesehatan, 7(1), 17-20.

Kartono, B. (2008). Hubungan Lingkungan Rumah dengan Kejadian Luar Biasa Difteri di Kabupaten Tasikmalaya (2005-2006) dan Garut Januari 2007. Jurnal Kesehatan., 12(1), 8-12.

Mariana, D., \& Hairuddin, M. C. (2018). Kepadatan Hunian, Ventilasi Dan Pencahayaan Terhadap Kejadian Tb Paru Di Wilayah Kerja Puskesmas Binanga Kabupaten Mamuju Sulawesi Barat. Jurnal Kesehatan Manarang, 3(2), 75 . https://doi.org/10.33490/jkm.v3i2.40

Rosiana, A. M. (2012). Hubungan Antara Kondisi Fisik Rumah dengan Kejadian TB Paru, Semarang. Universitas Negeri Semarang.

Sejati, A., \& Sofiana, L. (2015). Factors Occurrence of Tuberculosis. Journal of Public Health, Indonesia, 10(2), 122 - 128. http://journal.unnes.ac.id/nju/index.php / kemas/article/view/3372

Sinaga, H. (2019). Examination Of Pulmonary Tuberculosis Patients At The Regional Generalhospital (RSUD) Jayapura. Jurnal
Riset Kesehatan, 8(2), $21-26$. https:// doi.org/10.31983/jrk.v8i2.5364

Wati, I., Kurniawan, T., \& Nugraha, B. A. (2020). Gambaran Self Efficacy Pada Pasien $\mathrm{Tb}$ Paru Untuk Menyelesaikan Pengobatan Di Poli Dots Pada Salah Satu Rumah Sakit Umum Daerah Di Garut. Jurnal Keperawatan ' Aisyiyah, 6(2), $67-78$. https://doi.org/10.33867/jka.v6i2.120

Yigibalom, N., Sulistiyani, S., \& Nurjazuli, N. (2019). Faktor Risiko Kebiasaan Tinggal di Rumah Etnis dan Membuang Dahak Sembarang pada Kejadian TB Paru Di Kabupaten Jayawijaya, Papua. Jurnal Kesehatan Lingkungan Indonesia, 18(1), 1. https://doi.org/10.14710/jkli.18.1.1-7

Fitzgerald, L. E., Abendaño, N., Juste, R. A., \& Alonso-hearn, M. (2014). Three-Dimensional In Vitro Models of Granuloma to and Resuscitation of Dormant Mycobacteria. 2014.

Wulandari, A. A., Nurjazuli and Adi, M. S. (2015) 'Risk Factor and Potential of Transmission of Tuberculosis in Kendal District, Central Java', Jurnal Kesehatan Lingkungan Indonesia, 14, p. 1.

Andreas Christian Ayomi. Faktor Risiko Lingkungan Fisik Rumah dan Karakteristik Wilayah Determinan Kejadian Penyakit Tuberkulosis Paru di Wilayah Kerja Puskesmas Sentani Kabupaten Jayapura Provinsi Papua. Jurnal Kesehatan Lingkungan Indonesia, Vol. 11, No. 1, 1-8, 2012.

Sukmajati, Struktur dan Konstruksi: Konstruksi dan Pola Lantai, Jakarta, Universitas Mercubuana, 2010.

Widoyono, Penyakit Tropis: Epidemiologi, Penularan, Pencegahan, dan Pemberantasannya, Edisi ke-2, Semarang, Erlangga, 2011.

Lyzigos, Melissa, Natural Ventilation Reduces High TB Transmission Risk in Traditional Homes in Rural Kwazlu-Natal, South Africa, BMC Journal Infectious Disease, 13: 300, 2013.

Umar Fahmi Achmadi, Manajemen Penyakit Berbasis Wilayah, Jakarta, UI-Press, 2008.

Hidayat, H., (2012). "Hubungan Sanitasi Fisik Rumah Dengan Kejadian Penyakit TB Paru di Desa Kalikatak Kecamatan Arjasa Kabupaten Sumenep". Skripsi. Surabaya: Universitas Airlangga. 
Jurnal Riset Kesehatan, 10 (1), 2021, 70 - 70

DOI: $10.31983 /$ jrk.v10i1.6694

Ndungu, Perpetual Wangui, Risk Factor in the Transmission of Tuberculosis in Nairobi: A Descriptive Epidemiological Study,
Kenya, Scientific Research: Advances in Microbiology, 3: 160-165, 2013.

Joko Suryo. 2020. Herbal Penyembuh Gangguan Sistem pernapasan. Yogyakarta. B. First. 